\title{
Henna-induced acute hemolysis in an elderly woman: a rare case report from the Maldives
}

\author{
Rajib Kumar Dey ${ }^{1 *} \mathbb{D}$, Ali Abdulla Latheef ${ }^{1}$, Hisham Ahmed Imad² and Moosa Murad ${ }^{1}$
}

\begin{abstract}
Background: Glucose-6-phosphate dehydrogenase enzyme deficiency is the most common enzymopathy in the world with a high prevalence in people of sub-Saharan Africa, Asia, and Mediterranean region. Being an X-linked recessive disorder, majority of the patients are males, and women get affected only if they are homozygous or double heterozygous for G6PD mutants. These patients are usually asymptomatic and present with an acute episode of hemolytic anemia when exposed to certain medications, chemicals, infections, fava beans, or any oxidative stress.

Case presentation: Here, we report a rare case of acute hemolytic anemia in an elderly woman following exposure to henna. On evaluation, she was found to be G6PD-deficient. We postulate that with increasing age, there is an increase in the amount of skewing about $70-90 \%$ in women above 70 years old which may lead to hemolysis in G6PD-deficient patients.

Conclusion: We advise all healthcare workers to keep a close eye and screen for G6PD deficiency in all elderly women presenting with acute hemolytic anemia.
\end{abstract}

Keywords: Glucose-6-phosphate dehydrogenase deficiency, Henna, Hemolytic anemia

\section{Background}

Glucose-6-phosphate dehydrogenase (G6PD) enzyme deficiency is the most common enzymopathy in the worldwide affecting more than 400 million individuals [1]. It has a high prevalence in people of sub-Saharan Africa, Asia, and Mediterranean region. The severity of the disease varies with different ethnic groups [2].

Majority of the G6PD-deficient patients are males as it is an X-linked recessive disorder. Females are affected only if they are homozygous or double heterozygous for G6PD mutations. The patients are usually asymptomatic but can present as an acute episode of hemolytic anemia when exposed to some specific drugs, chemical agents, fava beans, oxidative stress, bacterial, and viral infections [1]. Henna, which is widely used in many parts of the

\footnotetext{
*Correspondence: dr_rajibdey@yahoo.co.uk

1 Department of Medicine, Indira Gandhi Memorial Hospital, Malé,

Maldiveshttps://www.igmh.gov.mv/

Full list of author information is available at the end of the article
}

world for cosmetic reasons, has been reported to cause severe hemolysis in infants and children [3].

Here, we report an elderly woman who presented to the hospital with acute hemolytic anemia after applying henna. We highlight the importance of screening for G6PD enzyme deficiency in every acute hemolytic anemia patient irrespective of sex.

\section{Case presentation}

An 80-year-old woman presented to the emergency department with complaints of generalized weakness, fatigability, and yellowish discoloration of both eyes since past 1 day. There was no history of fever, nausea, vomiting, abdominal pain, or any pruritus. The patient did not give any such similar history in the past. Patient gave history of applying henna on her both hands and feet 3 days prior to the onset of these symptoms. She is a known case of old ischemic stroke, coronary artery disease, hypertension, and dyslipidemia. Her regular medications include aspirin, statins, and losartan which she was taking since 
few years. Physical examination was unremarkable except for pallor, icterus, and tachycardia.

Her investigations showed a picture of hemolytic anemia (Hb-8.8 g/dl, reticulocyte count 5.7\%, LDH- $350 \mathrm{U} / \mathrm{L}$, direct and indirect coombs test- negative, total bilirubin $6.1 \mathrm{mg} / \mathrm{dl}$, indirect bilirubin $5.1 \mathrm{mg} / \mathrm{dl}$, ALT- $24 \mathrm{U} / \mathrm{L}$, AST- $30 \mathrm{U} / \mathrm{L}$ ). Viral serology was negative for hepatitis $\mathrm{B}$ and $\mathrm{C}$. Other causes of hemolysis like infections and exposure to chemical agents or any new medications were ruled out. Abdominal ultrasonography was normal.

Spectrophotometric analysis confirmed G6PD deficiency with $6.5 \mathrm{U} / \mathrm{g} \mathrm{Hb}$ (normal range 7-20.5 U/g Hb). Molecular typing could not be done as this facility was not available in the country.

We diagnosed her as a probable case of henna-induced acute hemolytic anemia in the setting of G6PD deficiency. The patient recovered after red blood cell transfusion and supportive treatment. Her anemia and jaundice improved and liver function test normalized within 2 days. The patient did not have any more hemolytic episodes during the hospital stay. On follow-up after 2 months, the patient was clinically fine with no more episodes of hemolysis.

\section{Discussion}

Henna is a dye, prepared from the dried leaves of the plant Lawsonia inermis. It is commonly used in Asia, Africa, and Middle East during the ceremonial occasions, weddings, and circumcisions to color hair, nails, and also the skin by creating different patterns and designs [4].

Lawson (2-hydroxy-I,4 naphthoquinone) is an important chemical compound found in henna which constitutes about $1 \%$ by weight of the crushed leaves. Its structure and redox potential are similar to that of one of the naphthalene metabolites, 1,4-naphthoquinone, a potent oxidant of G6PD enzyme-deficient red cells. In vitro studies indicate that Lawson is also capable of causing oxidative injury to G6PD enzyme-deficient red blood cells [4].

To our knowledge, this is the first reported case of acute hemolytic anemia in an elderly woman which was induced by henna application on her hands and feet. She does not give history of hemolytic anemia in the past even though she has used henna. She denies taking any medications or substance that is known to cause hemolytic anemia. She was found to have G6PD deficiency during evaluations. Henna is known to cause hemolysis but in this case there was no hemolysis until advanced age made her more vulnerable to hemolysis. This genetic defect was silent until she was 80 years old when she developed her first hemolytic crisis following henna application.
Studies have shown that an increase in G6PD deficiency occurred due to differential skewing of $\mathrm{X}$ chromosome inactivation in elderly women [5]. This effect is likely due to an unbalanced X-chromosome inactivation pattern arising gradually in life and predominantly affecting the X-chromosome carrying the normal G6PD gene. Skewing increases with age. Significant skewing of $\mathrm{X}$ chromosome-inactivation is seen in 70 to $90 \%$ of women over the age of 70 years [6]. Therefore, in females heterozygous for $\mathrm{X}$-linked recessive genes, an increased frequency of clinical manifestations might be expected with increasing age, due to G6PD activity related to the degree of skewing of $\mathrm{X}$-inactivation. These deficiencies will not be detectable at birth during the population-wide screening programs [7].

In a population with high prevalence of G6PD deficiency, the male patients are routinely screened before prescribing any drugs with oxidizing properties. On the contrary, women are rarely screened for G6PD deficiency as double heterozygosity and homozygosity frequencies for G6PD mutations are presumed to be very low. This may be the case in young women but not in elderly where skewing of X-chromosome inactivation may occur, leading to severe hemolytic crisis in patients.

\section{Conclusion}

It is important to screen for G6PD activity in all elderly women presenting with acute hemolytic anemia. A detailed history should be taken to exclude any recent exposure to henna especially in countries with high prevalence of G6PD deficiency. A local public awareness program should be established to educate people about the disease.

\section{Abbreviations}

G6PD: Glucose-6-phosphate dehydrogenase enzyme; Hb: Hemoglobin; LDH: Lactate dehydrogenase; ALT: Alanine aminotransferase; AST: Aspartate aminotransferase.

\section{Acknowledgements}

The authors are sincerely grateful to the patient who volunteered to be part of this report, and a special thanks to all the staff at the Department of Medicine at Indira Gandhi Memorial Hospital.

\section{Authors' contributions}

Conceptualization, R.K.D., A.A.L., and M.M.; methodology, R.K.D., A.A.L., and M.M.; software, R.K.D.; validation, R.K.D. A.A.L and M.M.; formal analysis, R.K.D., A.A.L., and M.M.; investigation, R.K.D. A.A.L and M.M.; resources, R.K.D. A.A.L and M.M.; data curation, R.K.D.; writing - original draft preparation, R.K.D; writingreview and editing, R.K.D., A.A.L, M.M., and H.A.I.; supervision, A.A.L., and M.M. All authors have read and agreed to the published version of the manuscript.

Funding

The authors have not received funding in any form. 
Availability of data and materials

The data presented in this study are available on request from the corresponding author. The data are not publicly available to ensure the privacy of the study participant.

\section{Declarations}

Ethics approval and consent to participate

Not applicable.

\section{Consent for publication}

Oral and written informed consent were obtained from the patient.

\section{Competing interests}

The authors declare that they have no competing interests.

\section{Author details}

'Department of Medicine, Indira Gandhi Memorial Hospital, Malé, Maldiveshttps://www.igmh.gov.mv/. ${ }^{2}$ Mahidol Vivax Research Unit, Faculty of Tropical Medicine, Mahidol Universityhttps://mahidolvivax.com/en-US/.

Received: 16 December 2021 Accepted: 1 February 2022

Published online: 02 March 2022

\section{References}

1. Cappellini MD, Fiorelli GE (2008) Glucose-6-phosphate dehydrogenase deficiency. Lancet. 371(9606):64-74

2. Crook MA (2012) Clinical biochemistry and metabolic medicine, 8th edn. Hodder \&Stought Ltd, p 383

3. Raupp P, Hassan JA, Varughese M et al (2001) Henna causes life threatening haemolysis in glucose-6-phosphate dehydrogenase deficiency. Arch Dis Childhood 85:411-412

4. Zinkham WH, Oski FA (1996) Henna: a potential cause of oxidative hemolysis and neonatal hyperbilirubinemia. Pediatrics. 97:707-709

5. Au WY, Ma ES, Lam VM, Chan JL, Pang A, Kwong YL (2004) Glucose 6-phosphate dehydrogenase (G6PD) deficiency in elderly Chinese women heterozygous for G6PD variants. Am J Med Genet Part A. 129(2):208-211

6. Van Dijk JP, Heuver L, Stevens-Linders E, Jansen JH, Mensink EJ, Raymakers RA, de Witte T (2002) Acquired skewing of Lyonization remains stable for a prolonged period in healthy blood donors. Leukemia. 16(3):362-367

7. Lam STS, Cheng ML (2003) Neonatal screening in Hong Kong and Macau. Southeast Asian J Trop Med Public Health. 34(3):73-5

\section{Publisher's Note}

Springer Nature remains neutral with regard to jurisdictional claims in published maps and institutional affiliations.

\section{Submit your manuscript to a SpringerOpen ${ }^{\odot}$ journal and benefit from:}

- Convenient online submission

- Rigorous peer review

- Open access: articles freely available online

- High visibility within the field

- Retaining the copyright to your article 